\title{
IL-13Ra2/AP-1 complex signalling mediates airway epithelial repair without effects on remodeling pathways
}

\author{
Jasemine S Yang ${ }^{*}$, Sima Allahverdian, Gurpreet K Singhera, Ruth E MacRedmond, Delbert R Dorscheid \\ From AllerGen NCE Inc.'s Fifth Annual Research Conference: Innovation from Cell to Society \\ Québec City, QC, Canada. 7-9 February 2010
}

\section{Objective/purpose}

The airway epithelium serves as a physical defense barrier to the external environment for the underlying tissue and suffers frequent injury. The response to injury is inflammation followed by debris clearance and repair. Although IL-13 is known to be a key cytokine in mediating inflammatory and remodeling responses via signal transducer and activator of transcription 6 (STAT6) and early growth response protein 1 (Egr1), our laboratory has demonstrated that IL-13 is critical to airway epithelial repair via the release of heparin-binding epidermal growth factor (HB-EGF) and activation of epidermal growth factor receptor (EGFR). IL-13 signals through two receptors, IL-13R $\alpha 1 / \mathrm{IL}-4 \mathrm{R}$ and IL-13R $\alpha 2$. IL-13R $\alpha 2$ has previously been thought to act exclusively as a decoy receptor, however our findings show that IL$13 R \alpha 2$ can act as a signaling receptor and is involved in mediating airway epithelial repair. Differential signaling via IL-13R $\alpha 1$ or IL-13R $\alpha 2$ may determine a remodeling versus repair response to injury in airway epithelium.

\section{Methods}

IL-13R $\alpha 1$ and IL-13R $\alpha 2$ functions were disrupted in Human Airway Epithelial (1HAEo-) cells using specific IL-13R $\alpha 1$ and IL-13R $\alpha 2$ blocking antibodies and small interfering RNAs (siRNAs). 1HAEo- cells were also transfected with activator protein 1 (AP-1) specific and scramble siRNA. Following specific antibody blocking or siRNA transfection, 1HAEo- cells were either stimulated with IL-13 (10 ng/ml) or mechanically injured. Supernatants and protein lysates were collected at different time points. Expressions of phospho-STAT6, STAT6, Egr1,

UBC James Hogg Research Centre, Providence Heart + Lung Institute, St. Paul's Hospital and Faculty of Medicine, University of British Columbia, Vancouver, BC, Canada and AP-1 were detected via Western blotting, while HBEGF release in supernatants was quantified using ELISA. Furthermore, AP-1 activity in 1HAEo- cells after IL-13 stimulation or mechanical injury was measured using an AP-1-luciferase assay.

\section{Findings}

IL-13 stimulation resulted in upregulation of phosphoSTAT6, Egr1 and AP-1 expression. AP-1 expression correlated with activity as determined by AP-1 luciferase assay. Following mechanical injury, the expression of phospho-STAT6 and Egr1 was inhibited when IL-13R $\alpha 1$ function was disrupted, while induction of AP-1 expression is unchanged. In contrast, when IL-13R $\alpha 2$ function was disrupted, HB-EGF and AP-1 expression was inhibited while STAT6/Egr1 signaling remains intact. Gene silencing of AP-1 had no effect on phospho-STAT6 expression in response to injury, however HB-EGF expression was significantly inhibited compared to scramble siRNA treated cells.

\section{Deliverables}

Our data indicates that IL-13 mediates repair of airway epithelial cells via IL-13R $\alpha 2$ and AP-1, while remodeling responses downstream of STAT- 6 and EGR-1 are signaled via IL-13 R $\alpha 1$.

\section{Relevance}

Strategies directed towards augmentation of the IL$13 R \alpha 2 / A P-1$ pathway may lead to novel therapies which target the dysfunctional repair phenotype in asthmatic epithelium without adverse effects on airway remodeling. 
doi:10.1186/1710-1492-6-S3-P27

Cite this article as: Yang et al: IL-13R 2 2/AP-1 complex signalling mediates airway epithelial repair without effects on remodeling pathways. Allergy, Asthma \& Clinical Immunology 2010 6(Suppl 3):P27.

Submit your next manuscript to BioMed Central and take full advantage of:

- Convenient online submission

- Thorough peer review

- No space constraints or color figure charges

- Immediate publication on acceptance

- Inclusion in PubMed, CAS, Scopus and Google Scholar

- Research which is freely available for redistribution

Submit your manuscript at www.biomedcentral.com/submit
C Biomed Central 